\title{
Response of Plant Hormone Bioassay to Paclobutrazol
}

\author{
Ashok Kumar ${ }^{1 *}$, C.P. Singh ${ }^{2}$, Sant Ram ${ }^{3}$ \\ ${ }^{1}$ Professor, Department of Agriculture, Himalayan Institute of Technology, Asthal Campus, Raipur, Dehradun \\ U.K. India. \\ ${ }^{2}$ Professor, Department of Horticulture, G.B.P.U.A\&T-Pant Nagar, U.P., India. \\ ${ }^{3}$ Professor, Department of Horticulture, G.B.P.U.A\&T-Pant Nagar, U.K. India
}

*Corresponding Author: Ashok Kumar, Professor, Department of Agriculture, Himalayan Institute of Technology, Asthal Campus, Raipur, Dehradun U.K. India.

\begin{abstract}
Quantitative estimation of a known or suspected biologically active substance (such as a hormone or drug) by measuring its effect on a living organism in standard conditions is known as bioassay.The interaction of gibberellic acid (GA3) and paclobutrazol (PBZ) in lettuce hypocotyl bioassay and 6-benzyl aminopurine (BAP) and paclobutrazol in radish cotyledon enlargement test that paclobutrazol counteracts gibberellin activity when applied exogenously. The radish cotyledon enlargement at low concentration without counteracting BAP action. The reduction of growth to be counteracting of gibberellin activity by paclobutrazol as well as its cytokinin well activity at lower concentration which indicate concentration of gibberellins activity as evidence by their respective bioassay in the present investigation. Paclobutrazol slightly increased radish cotyledon growth at low concentration (up to $0.01 \mathrm{ppm}$ ) and could not counteract the growth caused by $1.0 \mathrm{ppm}$ BAP at its 0.001 to $1.0 \mathrm{ppm}$ concentrations suggesting independent effect of paclobutrazol to that of BAP. Furthermore, the activity of paclobutrazol was tested in corn root curvature test and it was found that PBZ concentrations from 0.001 to 10.0 ppm linearly increased the percentage of corn roots showing more than $90^{\circ}$ curvature. Therefore, suggession that PBZ conutracted GA3, induced growih and also as IAA and cytokinin at lower concentration0.001 to 100ppm.
\end{abstract}

Keywords: Paclobutrazol, PBZ,Auxins, Gibbrellins, Bioassay, Cytokinens, Abscisic Acids,Ethylene, Paper chromatography, radish, cotyledons, hypocotyls, BAP

\section{INTRODUCTION}

Paclobutrazol is a trizol derivative (2RS 3RS)-1-(4-Chlorophenyl)-4, 4-dimethyl-2-(1.2, 4-Trizol-1-yl) Pentan-3-ethanol. Paclobutrazol was taken up through the root and was transported primarily in the xylem through the stem and accumulated in the leaves (Wang et al, 1986). Paclobutrazol is a potent regulator of gibberellins biosynthesis and inhibits the oxidation of kaurene to kaurenoic acid. Specifically, it interacts with kaurene oxidase, a cytochrome P-450 oxidase, and inhibits the microsomal oxidation of kaurene, kaurenal, and kaurenol (Hedden and Graebe, 1985). Reduced levels of gibberellins lead to a decrease in cell division and elongation at the apical meristem of the shoot, but has little effect on the production of leaves or root growth (Giafagna, 1995). Paclobutrazol must be translocated to the meristematic region and maintain a threshold concentration for efficacy (Lever, 1986). It is often referred to as an "anti-gibberellin" because physiological treatment effects can be reversed by the application of GA (Cox, 1991). However, this term is misleading because paclobutrazol does not block the activity of existing endogenous or applied exogenous GA3 (Lever, 1986) by competing for the same active site. Instead, paclobutrazol should be referred to as a "gibberellin inhibitor." Transport of paclobutrazol occurs passively in the xylem (Barrett and Bartuska, 1982; Wang et al., 1986; Early and Martin, 1988), with little to no movement in the phloem (Richardson and Quinlan, 1986). It was proposed that transpiration was required to draw the chemical through the xylem to the meristematic regions (Lever, 1986) and confirmed by Early and Martin (1988), who demonstrated using 14C-paclobutrazol that the pattern of radioactivity followed the pathway of normal water movement. A previous study indicated that paclobutrazol uptake from solution and movement within tissue was rapid, with significant levels of labeled material detected 
within 12 hours of treatment (Early, 1986). Movement of paclobutrazol in the plant is acropetal, with no movement out of mature leaves (Richardson and Quinlan, 1986; Early and Martin, 1988). Accumulation within a plant is primarily in root and leaf tissue, with one study determining $~ 80 \%$ of labeled material accumulated in basal and midsection leaves (Early and Martin 1988). Only a small portion of applied paclobutrazol actually reaches the site of action. Metabolism is generally thought to occur very slowly within plant tissue, but there have been differing reports. Early and Martin (1988) reported that breakdown of paclobutrazol ranged from 32 to $58.5 \%$, with most degradation occurring in leaf tissue, as only 7.8 to $12.2 \%$ of $14 \mathrm{C}$ activity remained as paclobutrazol nine days after treatment. However, Sterrett (1985) reported in apple that $85 \%$ of $14 \mathrm{C}$ activity in shoot tissue remained as paclobutrazol 27 days after injection. Degradation of paclobutrazol occurs in soil under aerobic conditions and mesophilic temperatures due to microbial activity (Jackson et al., 1996). Gibberellins are synthesized from mevalonic acid via the isoprenoid pathway and the paclobutrazol specifically inhibit the microsomal oxidation of kaurene, kaurenol and kaurenal catalyzed by kaurene oxidase (Hedden and Graebe 1985). Kurian et al. (1992) reported that soil drenched with $2.5 \mathrm{~g}$ PBZ per mango tree had lower activity of zeatin, zeatin riboside, isopentenyl adenosine and isopentenyl adenine than that of control plants. Therefore, present investigation was carried out to find out the interaction of gibberellins and paclobutrazol in lettuce hypocotyl bioassay, benzyl amino purine and paclobutrazol in radish cotyledon enlargement tests and activity of paclobutrazol in corn root curvature test. A major parts of paclobutrazol was taken into roots and mature leaves after soil drenching in hydroponics(Reed et al. 1989) and most of the PBZ ${ }^{14} \mathrm{C}$ actively in stem and leaves was located in the lowest part of the seedling. The constraction of ${ }^{14} \mathrm{C}$ paclobutrazol was highest in leaves (478dpm/mg FW), roots and stems $(141 \mathrm{dpm} / \mathrm{mg} \mathrm{FW})$ indicate that transport of compound was occuring via the xylem (Sugavan 1984) has been presented evidence from computer modelling with indicated that paclobutrazol can bind to both ent-Kaurene to Cytoclorome P-450 preventing P-450 from releasing $\mathrm{O}_{2}$ molecules from ent-Kaurene and thus blocked its oxidation to Kaurenol. Reduction of shoot growth by paclobutrazol is always accompanied by lowered content of gibberellins. Reduced level of gibberellins acid have been detected as a result of PBZ treatment (Lever, 1986; Hadden and Graebe, 1985). However, structure of Gibberellins A1, A3, A19, A20 and A53 were not altered by PBZ. The major changing by gibberellins activity was less associated with processes leading to germination allowing normal growth and development of seedings (Gianfanga and Rachmiel, 1986).Paclobutrazol caused reduced incorporation of acetate into 4-dimethyl sterol, compesterol, and sitosterol. stigmasterol and cycloeucalenol in cell culture of celery(Huang et al., 1987), overall growth of cell suspension was also inhibited by paclobutrazol and cholesterol could partially overcome inhebition(Huang et al. 1989). This suggested that paclobutrazol inhibited sterol biosynthesis. Out of four enantiomers of paclobutrazol(2RS, 3RS)-1-(4-Chlorophenyl)-2, 4-dimethyl-2- (1M-1, 2-4-trizol I-y)-pentan-3-1yl). Two enantionmers(2RS, 3S and 3R, 3S) inhibited growth and induced the synthesis of sterol, whereas the other two were inhibitory at high concentration only (Huang et al., 1987). PBZ inhibited sterol "C Oxidation demethylation during ergosterol biosynthesis (Ragsdale and Sisler, 1973). Therefore, present investigation was carried out to find out the interaction of gibberellins and paclobutrazol in lettuce hypocotyls bioassay, benzyl amino purine and paclobutrazol in radish cotyledon enlargement tests and activity of paclobutrazol in corn root curvature. It is possible that paclobutrazol inhibited sterol biosynthesis in the same manner as it in gibberellins biosynthesis.

\section{Materials ANd Methods}

The present investigation was carried out at laboratory of department of Horticulture, College of Agriculture of G.B. Pant University of Agriculture and Technology, Pant Nagar, India. Paclobutrazol activity was tested in corn root curvature test as described by Ram and Raina (1992). Five ml test solution (paclobutrazol 0.001 to $10 \mathrm{ppm}$ ) was pouredin each petriplate containing Whatman No.1 paper discs $(9.0 \mathrm{~cm})$. Ten seeds of corn cv. Sweta presoaked and thoroughly washed were arranged introversely on the periphery of paper discs. The petriplates were kept at $25 \pm 10 \mathrm{C}$ in dark. The number of roots having more than $90^{\circ}$ curvature were counted after 72 hours. The experiments were laid out in completely randomized block design and each treatment was replicated 5 times. Valid conclusions were drawn only on significant differences between the treatment means at 0.05 level of probability (Cochran and Cox 1950). 


\subsection{Bioassay}

\subsubsection{Bioassay of Auxins}

Auxins are weakly acidic growth hormones having an unsaturated ring structure and capable of promoting cell elongation, especially of shoots (more pronounced in decapitated shoots and shoot segments) at a concentration of less than $100 \mathrm{ppm}$ which is inhibitory to the roots. Among the growth regulators, auxins were the first to be discovered. Testing of biological activity (growth) of a substance (auxin) by employing living material is called bioassay. Auxin bioassay is also quantitative test as it measures amount of effect in response to a particular concentration of auxin. This test is based on the polar transport of the auxin in Avena coleoptiles. The auxin applied on one side of the cut coleoptiles stump will diffuse down that side only and will cause that side to grow more resulting in curvature of the coleoptiles. Within limits this curvature is directly proportional to the amount of auxin applied.
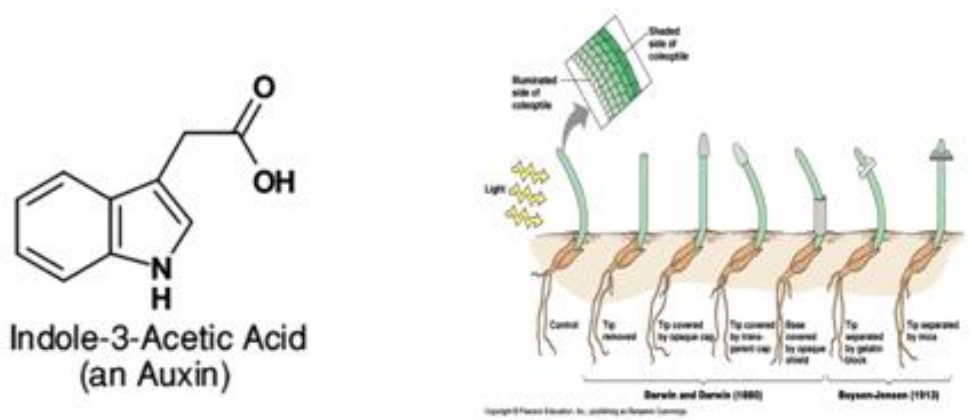

(1) Avena coleoptiles curvature test: Bioassay was carried out essentially as described by Bariond et al. (1957) and seed of oat cv. Kent were listed for the bioassay of auxins. The growth response of coleptile suction to different concentration of IAA/Paclobutrazol (0.001 to $100 \mathrm{ppm})$. Avena curvature test carried out by F.W. Went (1928), demonstrated the effect of auxins on plant growth by performing some experiments with the oat (Avena sativa L.) coleoptiles. Avena grains are germinated and grown in total darkness. The seedlings are exposed to short periods (2-4 hrs.) of red light two days after germination. When the roots are about $2 \mathrm{~mm}$. long, the seedlings are planted in special glass holders, using the water culture method .The straight coleoptile are selected .The tips of the coleoptile (about $1 \mathrm{~mm}$ ) are removed and placed on agar-agar. The agar is cut into blocks of standard size (usually $1 \mathrm{~mm}$ ), which now contain auxin. After about 3 hours a second decapitation of the coleoptiles (about $4 \mathrm{~mm}$ ) is made to remove the tip which might have regenerated and the first leaf of the seedling is pulled so that its connection from the base is broken .An agar block containing Auxin is now placed on one side of the cut coleoptile. The projecting primary leaf gives support to the Auxin block. After about 90 minutes the shadowgraphs of the seedlings are taken and the angle of curvature $(\alpha)$ is measured by drawing a vertical line and a line parallel to the curved portion of the coleoptiles. Within limits the curvature of the coleoptile is directly proportional to the concentration of Auxin in agar block. In case of Indole-3-Acetic Acid (IAA) the maximum response is at about $0.2 \mathrm{mg} / \mathrm{litre}$.

(2) Split pea stem curvature test: This test was also discovered by Went, 1934.

(3) Root growth inhibition test (Cress root inhibition test)

\subsubsection{Bioassay for Gibberellins}

A number of bioassays are known for gibberellins such as pea test, dwarf corn test, lettuce hypocotyl test, cucumber hypocotyl test, barley endosperm test, etc. The relative activity of the different gibberellins is different in different bioassay systems.

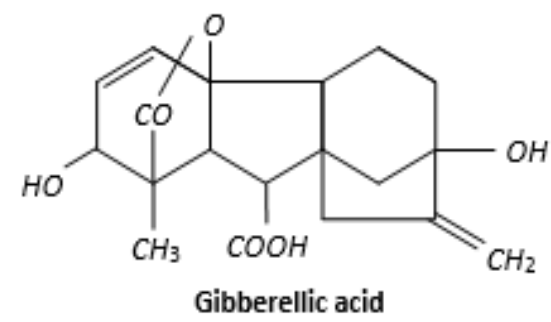


i Response of Paclobutrazol to lettuce hypocotyls growth test for Gibberellins: A number of bioassays are known for gibberellins such as pea test, dwarf corn test, lettuce hypocotyl test, cucumber hypocotyl test, barley endosperm test, etc. The relative activity of the different gibberellins is different bioassay systems. The lettuce hypocotyls bioassay test described by Frankland and Warling (1960) was used for the detection and estimation of levels of gibberellins like substances present on paper Chromatography. The hypocotyl growth response of lettuce seeding's to different concentration of Gibberellic Acid (GA3)/paclobutrazol (0.001- 100ppm) given in fig.3\&4

ii Dwarf Corn Test for Gibberellins: This bioassay is based on the fact that gibberellins cause elongation of the internodes, and in case of corn they also increase the length of the leaf sheaths which surround the internodes. The procedure of this bioassay is simple. A measured amount of the test solution in a suitable wetting agent is applied into the first unfolding leaf of corn seedlings when they are 6 to 7 days old. The seedlings are allowed to grow for 6 or 7 more days till the first and the second leaves are fully developed. The increase in the length of the first leaf sheath is measured and is plotted against the concentration of gibberellins applied. Within limits, a direct relationship is observed between the two.

iii. Barley Endosperm Test Gibberellins: This bioassay is probably the most widely used and is based on the fact that during germination of grains such as barley, wheat and oats, gibberellins is released from the embryo which moves to the aleurone cells where it induces synthesis of the enzyme $\alpha$ amylase. This enzyme hydrolyses starch into simple reducing sugars. (i) Barley seeds are cut in half transversely and the halves containing embryo discarded, (ii) Endosperm halves are sterilized and allowed to imbibe water for three days. (iii) Endosperm halves are now transferred to a flask containing buffer, $\mathrm{CaCl} 2$ and the test solution. Chloramphenicol is added to check bacterial contamination, (iv) After 24 hours of incubation at $25^{\circ} \mathrm{C}$ with shaking, the seeds are filtered off and the supernatant is analyzed for a-amylase activity (i.e., disappearance of starch and build up of reducing sugars), (v) Within limits, a direct relation is observed between conc. of gibberellins and aamylase. This bioassay is specific for Gibberellic Acid (GA3) and will detect a minimum of 0.2 nanogram of GA3.

\subsubsection{Bioassay for Kinetin (or, Cytokinins)}

A number of bioassays have also been devised for cytokinins, which are based on their specific physiological activities. They are Cell division tests, Chlorophyll preservation tests. Cell enlargement tests, Germination tests and Differentiation tests. A brief account of one of the cell division tests which are based on the induction of cell division in cytokinin-requiring tissue cultures is given below:

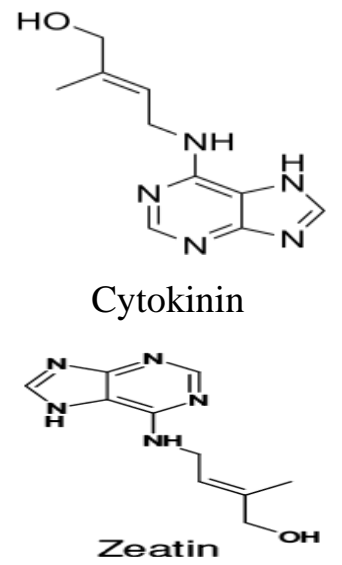

i. Response of PBZ to Radish Cotyledon enlargement test for cytokine:

Radish Cotyledon enlargement test as desired by Letham(1971) was used for the detection of cytokinin like activity. The response of Radish Cotyledon enlargement test to different concentration of cytokin/paclobutrazol (0.001 to 100ppm).

\section{ii Carrot Root Phloem Bioassay:}

Mature roots of cultivated carrot (Daucus carota var. sativus) are peeled and their surfaces sterilized . With the help of a special cutter they are cut into thin slices about 1-2 m.m. thick.With the help of a canula, secondary phloem explants are removed from a distance about $1.2 \mathrm{~m} . \mathrm{m}$. away from the 
cambium .The secondary phloem explants weigh about $2.5-3 \mathrm{mg}$. About three explants are inoculated into a culture tube containing $10 \mathrm{ml}$. of medium . The culture tubes are placed on a wheel which turns on a horizontal axis at $1 \mathrm{rpm}$, so that the explants are alternatively exposed to medium and the air.After a specified time (about 18-21 days) the explants are removed, weighed, macerated and the cells are counted. The number of the cells is converted into milligrams $(1 \mathrm{mg}$ being approximately equal to 10,000 cells) and is plotted against the time in days.

iii Bioassay for cytokinins using cucumber cotyledons:

The cucumber cotyledon greening bioassay is frequently used for detecting cytokinins. Beneficial modifications of the original technique included using 5-day-old cucumber (Cucumus sativus L., cv. National Pickling) cotyledons treated with combinations of 40 mill molar $\mathrm{KCl}$ and various concentrations of cytokinins. A dark incubation period of 20 hours was followed by an exposure to light for 3.5 hours. Under these conditions, extremely low ( 0.0001 milligram per liter) concentrations of N(6)-benzyl adenine, zeatin, kinetin, or zeatin riboside can be detected. of the four cytokinins tested, kinetin appeared to be the least active. With these improvements, the assay is 10 times more sensitive than is the previously described cucumber cotyledon greening bioassay for cytokinins

\subsubsection{Bioassay for Paclobutrazol}

\section{i. Response of $\mathrm{PBZ}$ to $>90^{\circ}$ Corn root curvature test:}

Paclobutrazol activity was tested and corn root curvature test as described by Curtis (1985) the response of PBZ to \% of corn root curvature test for the different concentration 0.001 to 100 ppm.Paclobutrazol activity was tested in corn root curvature test as described by Ram and Raina (1992). Five ml test solution (paclobutrazol 0.001 to $10 \mathrm{ppm}$ ) was poured in each petriplate containing Whatman No.1 paper discs $(9.0 \mathrm{~cm})$. Ten seeds of corn cv. Sweta presoaked and thoroughly washed were arranged introversely on the periphery of paper discs. The petriplates were kept at $25 \pm 10 \mathrm{C}$ in dark. The Number of roots having more than $90^{\circ}$ curvatures were counted after 72 hours. The experiments were laid out in completely randomized block design and each treatment was replicated 5 times. Valid conclusions were drawn only on significant differences between the treatment means at 0.05 level of probability (Cochran and Cox 1950).

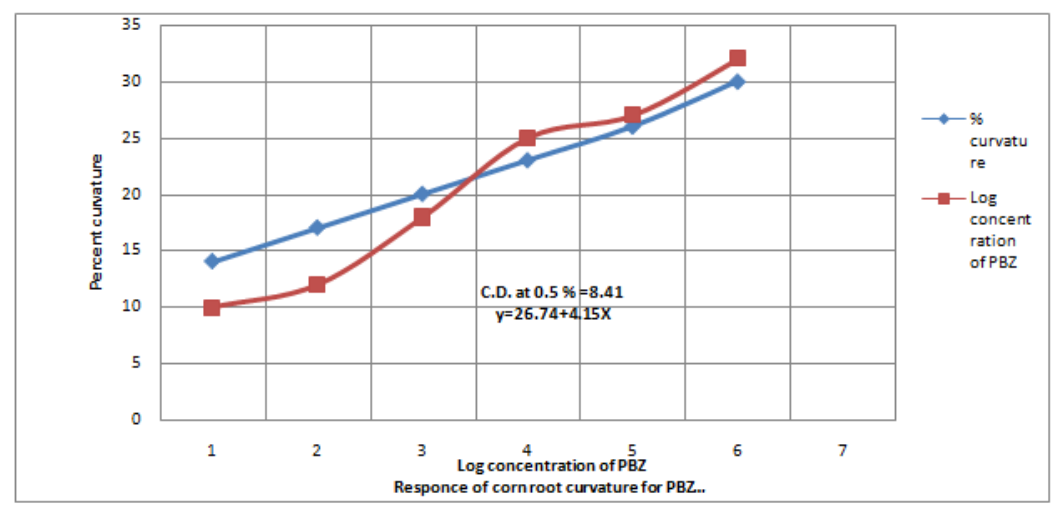

Fig1. Response of $\mathrm{PBZ}$ to $>90^{\circ}$ Corn root curvature test

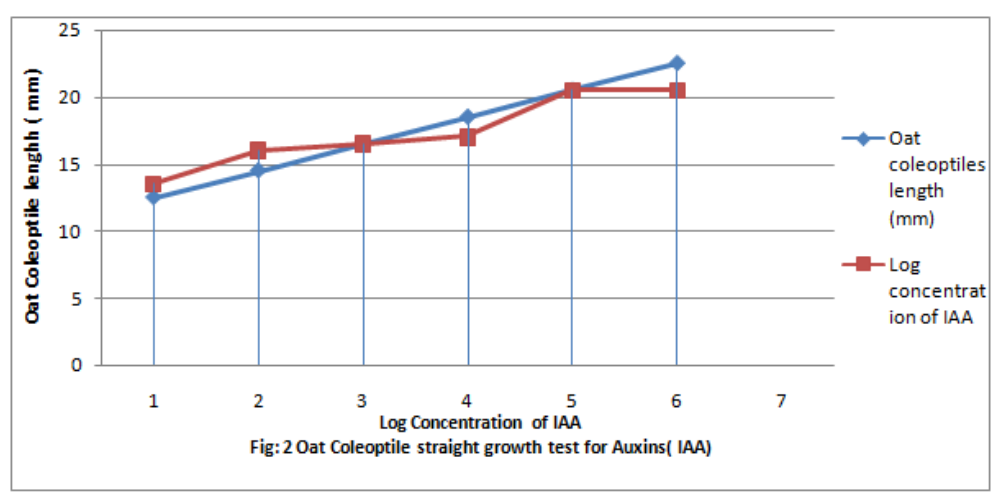

$Y=19.26+1.65$

C.D. at $0.5 \%=6.98$

Fig2. Oat Coleoptiles straight growth test for Auxin (IAA) 


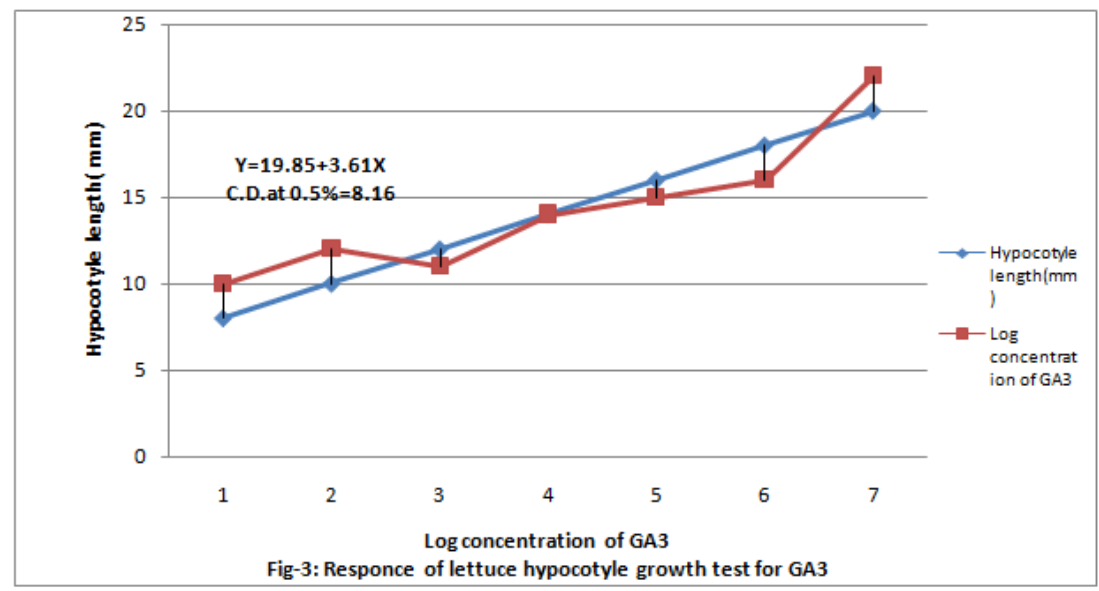

Fig3. Response of lettuce hypocotyls growth test for GA3

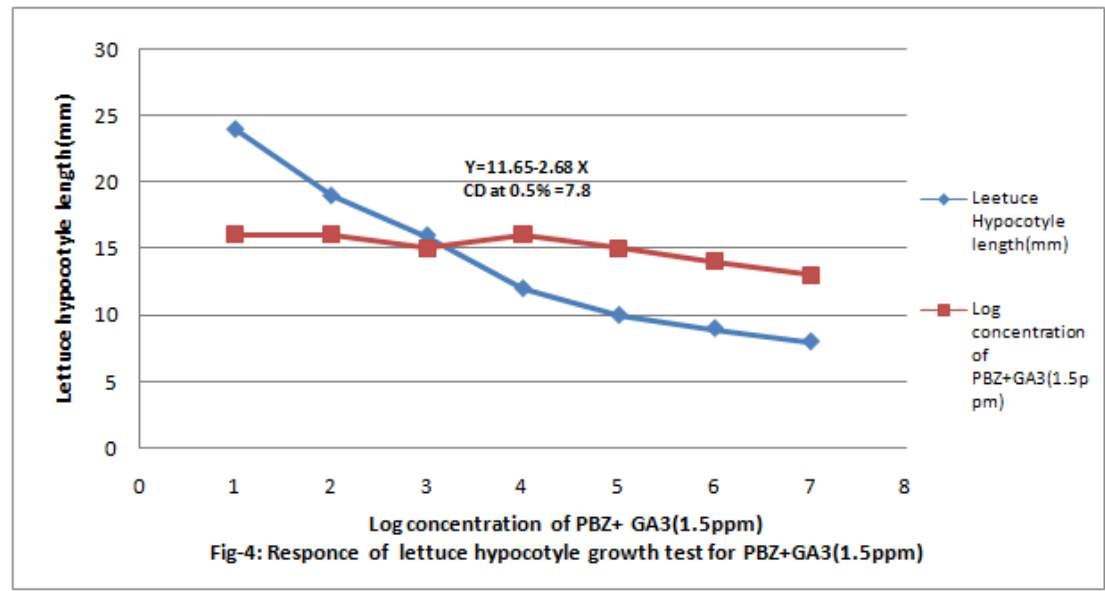

Fig4. Responses of lettuce hypocotyls growth test for PBZ+GA3 (1.5ppm)

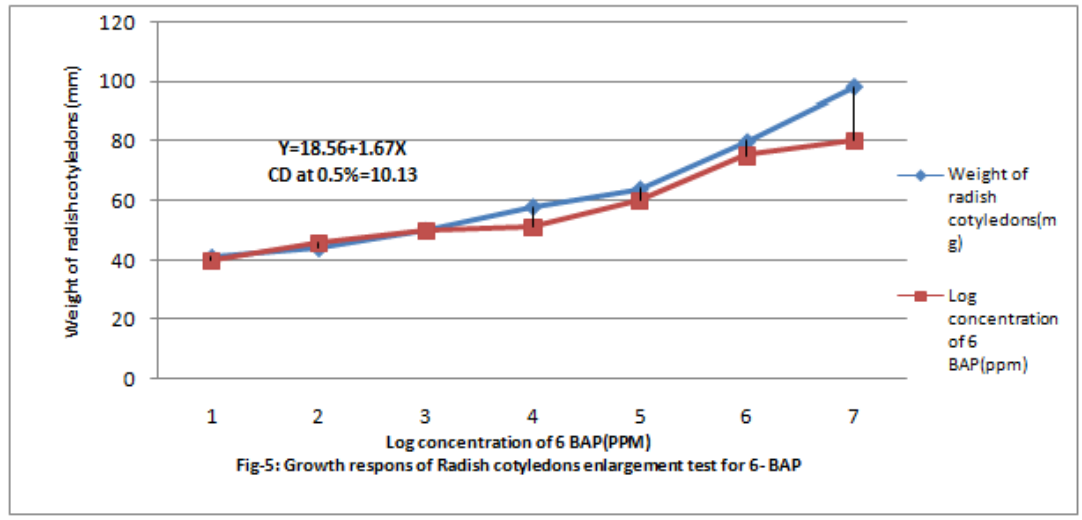

Fig5. Growth responses of Radish cotyledons enlargement test for 6-BAP

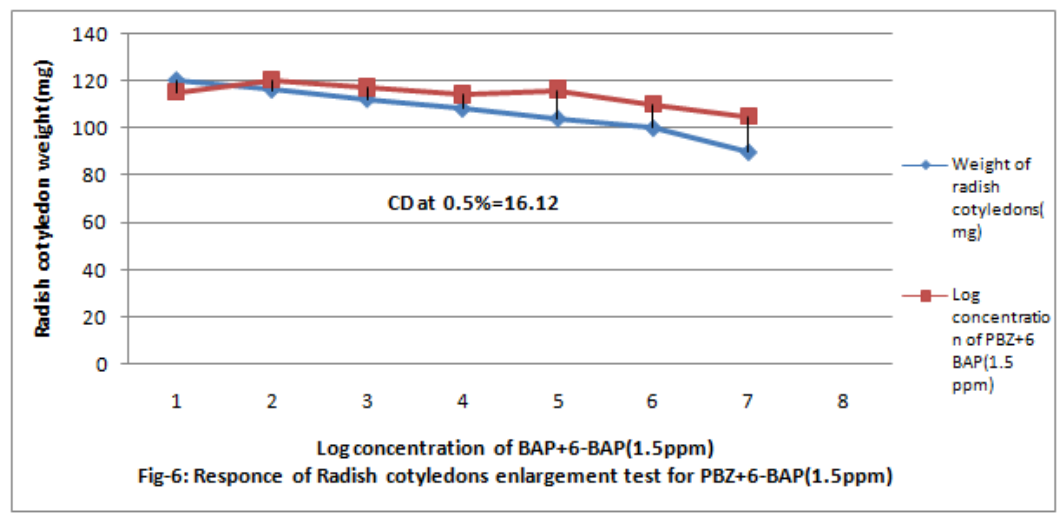

Fig6. Responses of Radish cotyledons enlargement test for PBZ+6-BAP (1.5ppm) 


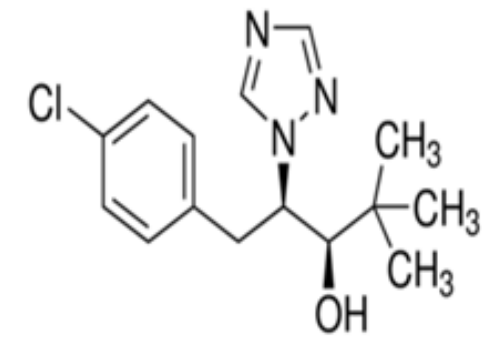

[Paclobutrazol (PBZ, PP333)]

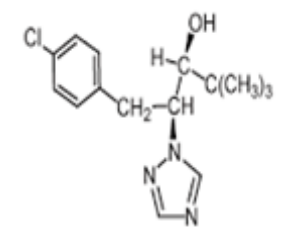

$(2 S, 3 S)$.

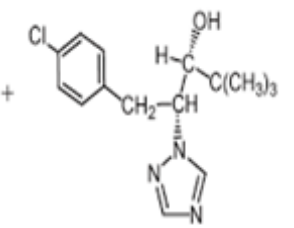

$(2 R, 3 R)$

[Paclobutrazol]
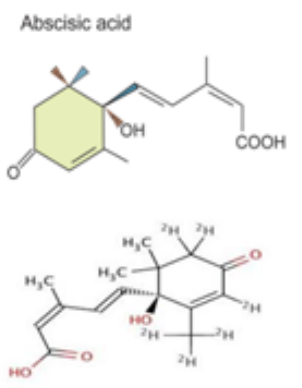

Table1. Effect of different dozes Paclobutrazol (PBZ) on corn roots curvature test

\begin{tabular}{|l|c|c|c|c|}
\hline $\mathbf{S . N .}$ & $\begin{array}{c}\text { Concentration } \\
(\mathbf{m g} / \mathbf{l})\end{array}$ & $\begin{array}{c}\text { No. of germinated } \\
\text { seeds outof 10 seeds of } \\
\text { Corn }\end{array}$ & $\begin{array}{c}\text { No. of seeds having a } \\
\text { curvature }\end{array}$ & $\begin{array}{c}\text { Percent roots with > 90 } \\
\text { \% curvature }\end{array}$ \\
\hline $\mathbf{1 .}$ & control & $10 / 10$ & 0 & 0.0 \\
\hline $\mathbf{2 .}$ & 0.001 & $10 / 9$ & 1.0 & 10 \\
\hline $\mathbf{3 .}$ & 0.01 & $10 / 9$ & 1.33 & 22.33 \\
\hline $\mathbf{4 .}$ & 0.1 & $10 / 9$ & 2.0 & 29.55 \\
\hline $\mathbf{5 .}$ & 1.0 & $10 / 8$ & 2.33 & 37.5 \\
\hline $\mathbf{6 .}$ & 10 & $10 / 8$ & 2.66 & 41.62 \\
\hline $\mathbf{7 .}$ & 100 & $10 / 8$ & 3.00 & \\
\hline
\end{tabular}

CD at $0.5 \%=8.41$

Table2. Rf value of Paclobutrazol as estimated by test after paper chromatography in solution system (Haxene: acetone $2: 1 \mathrm{v} / \mathrm{v}$ )

\begin{tabular}{|l|c|c|c|c|}
\hline S.N. & $\begin{array}{c}\text { Section } \\
\text { ( Rf) }\end{array}$ & $\begin{array}{c}\text { No. of germinated seeds } \\
\text { outof 10 seeds of Corn }\end{array}$ & $\begin{array}{c}\text { No. of seeds having a } \\
\text { curvature }\end{array}$ & $\begin{array}{c}\text { Percent roots with > } \\
\mathbf{9 0} \% \text { curvature }\end{array}$ \\
\hline & control & $\mathbf{1 0 / 1 0}$ & $\mathbf{1 . 0 0}$ & $\mathbf{1 0 . 0 0}$ \\
\hline $\mathbf{1 .}$ & 0.1 & $10 / 10$ & 1.00 & 0.00 \\
\hline $\mathbf{2 .}$ & 0.2 & $10 / 10$ & 0.00 & 0.00 \\
\hline $\mathbf{3 .}$ & 0.3 & $10 / 10$ & 0.00 & 0.00 \\
\hline $\mathbf{4 .}$ & 0.4 & $10 / 10$ & 0.00 & 0.00 \\
\hline $\mathbf{5 .}$ & 0.5 & $10 / 10$ & 0.00 & 0.00 \\
\hline $\mathbf{6 .}$ & 0.6 & $10 / 10$ & 2.00 & 22.22 \\
\hline $\mathbf{7 .}$ & 0.7 & $10 / 9$ & 5.00 & 22.50 \\
\hline $\mathbf{8 .}$ & 0.8 & $10 / 8$ & 2.00 & 0.22 \\
\hline $\mathbf{9 .}$ & 0.9 & $10 / 9$ & 0.00 & 0.0 \\
\hline $\mathbf{1 0}$ & 1.0 & $10 / 10$ & 0.0 & \\
\hline
\end{tabular}

CD at $0.5 \%=14.41$ 


\subsubsection{Bioassay for Abscisic Acid}

Abscisic Acid (ABA) is an isoprenoid plant hormone (phytohormone) synthesized in all parts of plants and involved in many plant developmental processes. ABA is involved in establishing dormancy and regulation of stress responses. ABA inhibits fruit ripening, seed germination, and photosynthesis and kinetin biosynthesis.

\subsubsection{Bioassay for Ethylene}

Ethylene bioassay why do the seedlings have to be kept in darkness? Is it possible to have them in sealed boxes that can be exposed to (constant) light at a fixed time every $24 \mathrm{hr}$ ? The test is conducted on etiolated pea seedlings, which have therefore been grown in the dark. Ethylene causes triple response on etiolated pea seedlings: reduced stem elongation, increased lateral growth of stem (swelling) and abnormal horizontal growth. The normal measurements that are taken are the increase in height of the pea seedlings and the intermodal length. Light would, of course, affect both of these. Furthermore, pea seeds have sufficient energy reserves to enable the growth to take place without light being necessary. Providing continuous controlled lighting in the field (and the test may be beside a road or in the centre of a field of wheat, for instance) is therefore an unnecessary complication, would invalidate the test (by affecting the very feature you are measuring) and would probably overheat the pea seedlings.

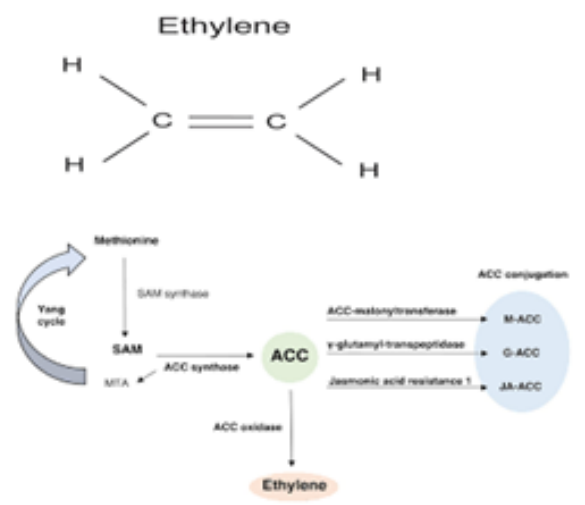

\section{STATiCAL Design}

The observation recorded were subjected to statically analysis by using $\operatorname{CRD}$ (Completely Randomized Design) for Lab Experiments. Valid conclusion was drawn only on significant differences between the treatment mean at 0.05 level of probability. On order to compare treatment mean, critical difference were calculated

\section{RESULT \& DISCUSSION}

\subsection{Experimental Result}

PlantHormone bioassay for IAA, Gibberellin. Cytokinins and Paclobutrazol named: Oat Coleoptile section straight growth test, lettuce hypocotyl growth test. Radish cotyledon enlargement test and corn root curvature test. Paclobutrazol was tested in different concentration (0.001 to 100ppm) in different bio assayed for Auxins, Gibberellins and Cytokinins.

\subsubsection{Oat Coleoptile Straight Growth Test for IAA}

Fig (1) show that 0.001 to 100 ppm IAA increased length of Oat coleoptile and the increase was linear to increase concentration of IAA. The linear equation is $\mathrm{Y}-19.26+1.65 \mathrm{x}$ and the CD at $0.5 \%$ level of significance is 6.98

\subsubsection{Response of PBZ to Lettuce Hypocotyl Growth Test for Gibberellins}

Fig(4\&5) show that 0.001 to 100 ppm PBZ decreased length of lettuce hypocotyl and it was linear to the increasing concentration of PBZ. Fig(5) show that PBZ 0.01 to $100 \mathrm{ppm}$ also contract the linearity the elongation of lettuce hypocotyl less caused by gibberellins. Thus PBZ inhibited growth of lettuce hypocotyl and also countered the growth caused by GA3 in lettuce hypocotyl bioassay, suggesting counteracting of growth caused by endogenous gibberellins. Applied exogenously in the medium. The regression equation is $\mathrm{Y}-19.85+3.61 \mathrm{X}$ and $\mathrm{CD}$ at $0.5 \%$ level is 8.16 


\subsubsection{Response of Radish Cotyledon Enlargement Test for Cytokinen}

Fig (5\&6) shows that 0.001 to ppm 6-BAP increase the growth of radish cotyledons. However, paclobutrazol increased the growth of radish cotyledon at 0.01 PPM but decreased when feed at 0.001 to 100ppm in the medium. Paclobutrazol slightly contracts the growth caused by 6-BAP. Paclobutrazol decreased cotyledon growth beyond $100 \mathrm{ppm}$. Thus, PBZ slightly increased radish cotyledon growth at lower concentration (up to $0.01 \mathrm{ppm}$ ). PBZ. Contracted growth of radish cotyledon enlargement with $1.5 \mathrm{ppm}$. The regression equation is $\mathrm{Y}=18.56+1.67 \mathrm{x}$, and $\mathrm{CD}$ at $0.5 \%$ level is $10.13 \%$.

\subsubsection{Response of Paclobutrazol to Corn Root Curvature Test}

Fig. (1) Show that $0.01 \mathrm{ppm}$ to $100 \mathrm{ppm}$ to increase the $\%$ of more than $90^{\circ}$ corn root curvature test. Fig. 6 further shows that PBZ also contracts the linearity of $>90^{\circ}$ corn root curvature test. The regression equation $\mathrm{Y}=26.74+$ at $0.5 \%$ level is 8.41 . The distribution of PBZ activity on paper developed in solvent system. Acetone: Hexane, 1: $2(\mathrm{v} / \mathrm{v})$ as bioassay by corn root curvature test, broken horizontal line indicate $\mathrm{CD}$ at $0.5 \%$ level of significance is 14.4. The RF value of PBZ in between $0.6 \& 0.7$.

\section{CONCLUSION}

Data(Fig.1) show that equation Y $26.74+4.15 x$ obtained during the standardization of corn root curvature bio assayed for estimation paclobutrazol(Table- 1), for this purpose, PBZ of the sample was extracted into dichloromethane fraction was described in materials was extracted into dichloromethane fraction by the employing chromatograms were bioassayed by the corn root curvature test developed by Curtis(1985). PBZ at lower concentration $(0.001$ to $100 \mathrm{ppm})$ the auxin like activity in Oat coleoplile straight growth test for IAA. Paclobutrazol slightly decreased the length of oat coleoptile. (Data not shown). The length of Oat coleoptile show leanerity in the present investigations. PBZ at lower concentration $(0.001$ to $100 \mathrm{ppm})$ also contract the linearity to the elongation of lettues hypocotyls length caused by gibberellins. The regression equation is $\mathrm{Y}=19.85+$ $3.61 \mathrm{X}$ and critical difference at $0.5 \%$ level is $8.16 \%$ the theory of contracting the length of hypocotyl of lettuce is that PBZ can bind to both ent-Kaurene to cytochrome P-450 preventing P-450 from, releasing $\mathrm{O} 2$ molecules from ent-Kaurene and thus blocked its oxidation to Kaurenol.In the case of Radish cotyledon enlargement test the PBZ at contracts the enlargement of radish glycodons with 1.5 ppm of PBZ but in the lower concentration(0.001) of PBZ increased cytokine activity same a gibberellins reasons is that mevalonic acid is precursor of cytokinins. The theme is that the reduction of growth to be counteracting of gibberellins activity by PBZ as well as cytokinins well activity at lower concentration which indicates concentration of gibberellins activity as evidence by their respective bioassay in thepresent investigation. Therefore suggestion that PBZ counteracted GA3 induced growth and also as IAA, Cytokinins at lower concentrations. However it is not known whether Paclobutrazolhas any effect directly or indirectly on the production of other class of hormone in the present investigations.

\section{ACKNOWLEDGMENT}

I take this opportunity to express my sincere thanks, profound sense of severance and gratitude to Dr. Sant Ram, Prof. and Dean PGS and Chairman my advisor committee for his valuable suggestions, guidance, kneen interest constructive criticism and unending encouragement during the course of these investigation and preparations of manuscript.

\section{REFERENCES}

[1] Buban, T. and Negy, M. 1987. Chanves in nucleic acid level of cell nuclei and hormone content in shoot tips of apple trees treated by paclobutrazol (cultar). Plant Growth Regulators. Proc. IV International Symposium of plant Growth Regulators, Part I [edited by Lilov, D.; Vassilev, G., Christov, C.: Andonova, T] 1987, 256-262, Sofia, Bulgaria

[2] Curtis, R.W. 1985. Root curvatures induced by culture filtrate of Aspergillus niger Science., 128: 661-662.

[3] Chandraparnik, S., Hiranpradit, H., Punnachit, U. and Salakpetch, S. (1992). Paclobutrazol influences flower induction in durian. Acta Hort. 321: 282-290.

[4] Cochran, W.G. and Cox, G.M. (1950). Experimental Designs (2nd Ed.). John Wiley and Sons, New York, USA. Dennis, F.G. Jr. and Nitsch, J.P. (1966). Identification of gibberellins A4 and A7 in immature apple seeds. Nature 211: 781-782. 
[5] El Hodairi, M.H. and Canham, A.E. (1990). The interacting effects of paclobutrazol and shading on the growth and flowering of maiden bramley's seedling apple trees. Acta Hort. 279: 363-376.

[6] Frankland, B. and Warling, P.E. 1960. The effect of gibberellic acid on hypocotyls growth of lettuce seedlings. Nature, 185: 255-256.

[7] Gianfanga, T.J. and Rachmiel, S. 1986. Changes in gibberellin like substances of peach seed during stratification. Physiologia Palntarum, 66: 154-158.

[8] Haughan P.A., Lenton J.R. and Goad, L.J. (1987). Paclobutrazol inhibition of sterol biosynthesis in a cell suspension culture and evidence of an essential role for 24- ethylsterol in plant cell division. Biochem. Biophys. Res. Commun. 146: 510-516.

[9] Henzell, R.F., Briscoe, M.R. and Gravett, I. (1992). Improving kiwi fruit vine productivity with plant growth regulators. Acta Hort. 297: 345-350.

[10] Hedden, P. and Graebe, J.E. 1985. Inhibition of gibberellin biosynthesis by paclobutrazol in cell-free homogenates of Cucurbita maxima endosperm and Malus pumila embryos. J. Plant Growth. Reg., 4: 111122.

[11] Huang, W.D. and Shen, T.I. 1987. The effects of PP 333 (Paclobutrazol) on the growth of seedlings of Pyrus betulaefolia Bge. and on the growth and fruiting of Yali pear (P. bretschneideri cv. Yali). Acta Hortic.,14: 223-231.

[12] Izumi, K.; Kamiya, A.; Sakurai, A.; Oshio, H. and Takahashi, N. 1985. Studies of sites of action of a new plant growth retardant (E)-1- (4-chloropheny)-4, 4-dimethyl-Z-(1.2,4-trizol-1-pentan-3-01) (S-3307) and comparative effects of its stereoisomers in a cell-free system from Cucurbita maxima. Plant Cell Physiol.26: 821-827

[13] Kur'yata, V.G., Berestetskii, V.A. and Negretskii, V.A. (1991). The hormonal status and growth characteristics of raspberry shoots as affected by GA and growth retardants. Fiziologiya I Biokhimiya kul'turnykh Rastenii. 23: 563-569.

[14] Kurian, RM. ; Murti, GS.R. and i yer, C.P.A. 1992. Changes in cytokinin level in mango, leaf extracts following soil drenches with paclobutrazol Gartenbauwissenchaft.,57: 84-87

[15] Kurian, R.M. and Iyer, C.P.A. 1992. Stem anatomical characters in relation to tree vigour in mango (Mangifera indica L.). Scientia Hort. 50: 245-253

[16] Kur'yata, VG.; Berestetski, V.A. and Negretskii, V.A. 1991. The hormonal status and growth characteristics of raspberry shoots as affected by GA and growth etar dants. Fiziologiya i Biokhimiya Kui'turnykh Rastenii.23: 563-569.

[17] Kur'yata, V.G.; Dabízhuk, T.M. and Remenyuk, G.L. 1991. Changes in morphogenesis, dormancy and frost resistance of raspberries as affected by retardants. Figiologiya I Biokhimiya Kul'turnykh Rastenii,23: 257-263.

[18] Letham, D.S. 1971. Regulators of cell division inplant tissues. XII. a cytokinin bioassay using excised radish cotyledons. Physiologia Plantarum.,25: 391-396.

[19] Lever, B.G. 1986. Cultar'-A Technical over view. Acta Hort., 179: 459-466.

[20] Martínez-Fuentes, A., Mesejo, C., Juan, M., Almela, V. and Agustí, M. (2004). Restrictions on the exogenous control of flowering in citrus. Acta Hort. 632: 91-98.

[21] Menzel, C.M. and Simpson, D.R. (1990). Effect of paclobutrazol on growth and flowering of lychee (Litchi chinensis). Aust. J. Exp. Agri. 30: 131-137.

[22] Norman S.M, R.D. Bennett, S.M. Polling, V.P. maier, MIDNEL son 1986. Paclobutrazol inhibits absusiv and siosynthesis in Cercosfoera rosorola. PlantPhysology.,12: 385-389.

[23] Norman, S.M.; Bennett, R.D.; Poling, S.M.; Maier, V.P. and Nelson, M.D. 1986. Paclobutrazol inhibits abscisic acid biosynthesis in Cercospora rosicola. PlantPlysiol. 80: 122-125.

[24] Obando, A., Alavez, J. and Darby, N. (1992). Effects of paclobutrazol on avocado (cv. Hass) in Mexico. Acta Hort. 321: 300-302.

[25] R. A. Fletcher, V. Kallidumbil, 1992. An improved bioassay for cytokinins using cucumber cotyledons, Plant Physiol. 69: 675-677

[26] Ragsdale, NN. and Sisler, H.D. 1973. Mode of action of triarimal in Ustilago maydis Pestic Bochem Dhysio, 31: 20

[27] Reed, AD. ; Curry, E.A. and williams, M.W.1989. Translocation of triazole growth retardants in plant tissues. J.Ameri. Soci. Hort. Sci., 114: 893-898.

[28] Ram, S. and Raina, K. (1992). Standardization of malformin bioassays and relationship between malformation intensity and malformin activity in mango. Acta Hort. 321: 412-424. 
[29] Shaltout, A., Salem, A.T. and Kilany, A. (1988). Effect of prebloom sprays and soil drenches of paclobutrazol on growth, yield, and fruit composition of 'Roumi Red' grapes. J. American Soc. Hort. Sci. 113: 13-17.

[30] Sugavanam, B. 1984. Diastereoisomeras and enantiomers of paclobutrazol: Their preparation and biological activity. Pestic. Sci., 15: 296-302.

[31] Tongumpai, P., Jutamanee, K. and Subhadrabandhu, S. (1991). Effect of paclobutrazol on flowering of mango cv. Khiew Sawoey. Acta Hort. 291: 67-70.

[32] Wang, S.V. and Faust, M. 1986. Effect of growth retardants on root formation and polyamine content in apple seedlings. J.Amer. Soc. Hort. Sci. 111: 912-917.

Citation: Ashok Kumar, et.al, "Response of Plant Hormone Bioassay to Paclobutrazol”, International Journal of Research Studies in Biosciences, 8(3), pp. 27-37. DOI: http://dx.doi.org/10.20431/23490365.0803004

Copyright: () 2020 Authors, This is an open-access article distributed under the terms of the Creative Commons Attribution License, which permits unrestricted use, distribution, and reproduction in any medium, provided the original author and source are credited. 